\title{
Analisis Distribusi Pemilikan Lahan Pertanian dan Pendapatan Usahatani di Kabupaten Karawang
}

\author{
Analysis of Agriculture Land Tenure Structure and Farmer Income in \\ Karawang Regency
}

Dwi Suprastyo ${ }^{1}$, Hermanto Siregar ${ }^{2}$ and Sri Mulatsih ${ }^{3}$

Diterima: 26 Desember 2017

Disetujui: 17 Agustus 2018

\begin{abstract}
Abstrak: Salah satu isu strategis di bidang pertanahan adalah timpangnya pemilikan lahan pertanian. Hal ini terjadi karena semakin mengecilnya lahan yang dimiliki oleh petani. Penelitian ini bertujuan untuk menganalisis bagaimana struktur pemilikan lahan pertanian dan pendapatan petani di Kabupaten Karawang serta kebijakan yang dapat diambil untuk mengatasi timpangnya pemilikan lahan pertanian. Di samping itu juga menganalisis berapa kebutuhan lahan yang ideal agar petani dapat memenuhi kebutuhan hidup layak keluarganya. Penelitian melibatkan dua desa yang mewakili daerah subur dan kurang subur. Data yang diperoleh dianalisis dengan menggunakan indeks gini, analisis chi square dan metode AHP dalam penentuan kebijakan. Hasil penelitian menyimpulkan bahwa masih terjadi ketimpangan pemilikan lahan serta pendapatan di antara petani. Terdapat dua kesimpulan mengenai hubungan luas lahan dengan pendapatan, di mana ada hubungan antara keduanya serta tidak ada hubungan antara keduanya. Upaya untuk mengatasi ketimpangan pemilikan lahan pertanian sekaligus pendapatan adalah salah satunya dengan mengeluarkan kebijakan pembatasan pemilikan lahan pertanian berdasarkan tingkat kehidupan layak.
\end{abstract}

Kata kunci: ketimpangan, pemilikan lahan, pendapatan, kebijakan pertanahan

\begin{abstract}
One of the strategic issues in the land sector is the lack of ownership of agricultural land. This happens because the shrinking land owned by farmers. This study aims to analyze how the structure of agricultural land tenure and income of farmers in Karawang regency and policies that can be taken to overcome the lack of agricultural land tenure. In addition it also analyzes how the ideal land requirement for farmers to meet the needs of their family's worth. The study involved two villages representing fertile and less fertile areas. The data obtained were analyzed by using gini index, chi square analysis and AHP method in determining policy. The results concluded that there is still an imbalance of land tenure and income among farmers. There are two conclusions about the relationship of land area to income, where there is a relationship between the two and no relationship between the two. Efforts to overcome the imbalance of agricultural land tenure as well as income is one of them by issuing policies limiting the ownership of agricultural land based on decent living level.
\end{abstract}

Keywords: inequality, land tenure, income, land policy

\footnotetext{
${ }^{1}$ Program Studi Ilmu Perencanaan Pembangunan Wilayah dan Perdesaan, Institut Pertanian Bogor

2 Departemen Ilmu Ekonomi, Institut Pertanian Bogor

${ }^{3}$ Program Studi Ilmu Perencanaan Pembangunan Wilayah dan Perdesaan, Institut Pertanian Bogor
}

Korespondensi:dwis.supra@gmail.com 


\section{PENDAHULUAN}

Ketimpangan pemilikan lahan pertanian merupakan isu strategis di bidang pertanahan selain isu jaminan kepastian hukum hak masyarakat atas lahan, kinerja pelayanan pertanahan dan ketersediaan lahan untuk pembangunan bagi kepentingan umum. Ketimpangan pemilikan lahan terjadi karena semakin mengecilnya lahan yang dikuasai dan dimiliki petani akibat pesatnya pembangunan dan pertambahan jumlah penduduk yang mengarah kepada ketidakadilan. Sensus Pertanian Badan Pusat Statistik, BPS (2013) seperti tersaji pada Tabel 1 menunjukkan bahwa 26.14 juta rumah tangga petani (RTP) hanya menguasai lahan rata-rata 0.89 hektar dan 14.25 juta RTP hanya menguasai lahan kurang dari 0.5 hektar per keluarga. Berdasarkan Sensus Pertanian 2013 jumlah RTP petani gurem di Jawa Barat sebanyak 2.298.193 RTP dari petani gurem yang ada di Indonesia. Upaya untuk mengatasi ketimpangan pemilikan lahan bukan merupakan hal yang mudah, mengingat masalah ini merupakan akumulasi dari berbagai aspek permasalahah yang terkait erat dengan aspek sosial budaya, ekonomi dan politik. Untuk meningkatkan kesejahteraan petani yang menguasai lahan pertanian gurem, maka salah satu agenda bidang pertanahan dalam RPJMN 2015-2019 akan meningkatkan akses petani gurem terhadap pemilikan lahan pertanian dari rata-rata 0.3 hektar menjadi 2 hektar per kepala keluarga petani (Kementerian PPN/Bappenas, 2014). Rustiadi (2008) menyatakan bahwa disparitas lahan pertanian dapat dilihat berdasarkan gini rasio kepemilikan lahan pertanian yang dipunyai oleh Rumah Tangga Petani.

Tabel 1 Jumlah Rumah Tangga Usaha Pertanian Menurut Golongan Luas Lahan yang Dikuasai, ST2003 dan ST2013

\begin{tabular}{ccrrrr}
\hline No & Golongan Luas & ST2003 & ST2013 & \multicolumn{2}{c}{ Perubahan } \\
\cline { 5 - 6 } & Lahan $\left(\mathrm{m}^{2}\right)$ & & & Absolut & $\%$ \\
\hline 1. & $<1000$ & 9.380 .300 & 4.338 .847 & -5.041 .453 & -53.75 \\
2. & $1100-1999$ & 3.602 .348 & 3.550 .185 & -52.163 & -1.45 \\
3. & $2000-4999$ & 6.816 .943 & 6.733 .364 & -83.579 & -1.23 \\
4. & $5000-9999$ & 4.782 .812 & 4.555 .075 & -227.737 & -4.76 \\
5. & $10000-19999$ & 3.661 .529 & $3,725,865$ & 64.336 & 1.76 \\
6. & $20000-29999$ & $1,678,356$ & $1,623,434$ & $-54,922$ & -3.27 \\
7. & $\geq 30000$ & 1.309 .896 & 1.608 .699 & 298.803 & 22.81 \\
\hline & Jumlah & 31.232 .184 & 26.135 .469 & -5.096 .715 & -16.32 \\
\hline
\end{tabular}

Sumber: Sensus Pertanian 2013,BPS

Luasan pemilikan lahan pertanian sebenarnya telah diatur melalui Undang Undang Nomor 56 Prp tahun 1960 tentang Penetapan Luas Tanah Pertanian.Undang-Undang tersebut menetapkan luas pemilikan lahan pertanian minimum sebesar 2 hektar per keluarga petani, agar dapat memperoleh penghasilan yang cukup untuk hidup layak bagi diri sendiri dan keluarganya. Namun luas lahan minimum yang telah ditetapkan untuk petani dalam kebijakan tersebut belum dapat diwujudkan dengan baik.

Upaya untuk mengetahui distribusi pemilikan lahan pertanian diperlukan dalam rangka menata kembali pemilikan lahan pertanian yang berkeadilan sehingga dapat menjadi tumpuan sumber pendapatan rumah tangga petani. Dalam rangka menata kembali pemilikan lahan pertanian tersebut, maka penelitian ini bertujuan untuk menganalisis distribusi pemilikan lahan dan pendapatan usahatani, menganalisis hubungan antara luas lahan dengan pendapatan, serta merumuskan kebijakan pertanahan yang dapat mengatasi ketimpangan. 


\section{METODE}

\section{Jenis dan Sumber Data}

Data yang dikumpulkan dalam penelitian ini berupa data primer dan data sekunder. Data primer bersumber dari data hasil inventarisasi penguasaan, pemilikan, penggunaan dan pemanfaatan lahan (IP4T). Data IP4T merupakan hasil survei yang dilaksanakan Kantor Pertanahan Kabupaten Karawang. Data primer IP4T tersebut didukung juga dari hasil wawancara (depth interview) dengan 5 responden ahli yaitu, pejabat Kantor Pertanahan Kabupaten Karawang, Dinas Pertanian Kabupaten Karawang, Bappeda Kabupaten Karawang, dan Kepala Desa Mulangsari serta Lemahduhur masing-masing satu orang. Data primer juga diperoleh dari wawancara terstruktur dengan petani sampel sebanyak masing-masing 35 orang dari Desa Mulangsari dan Lemahduhur. Jumlah ini sesuai kaidah sebaran normal (Singarimbun dan Sofian, 1995). Data sekunder bersumber dari data BPN dan BPS. Data sekunder dari BPN (Kanwil BPN Provinsi Jawa Barat dan Kantor Pertanahan Kabupaten Karawang) terutama data-data kegiatan IP4T, dan data lainnya yang dapat mendukung penelitian. Adapun data BPS terutama untuk data gambaran kondisi wilayah penelitian, seperti data luas dan batas wilayah, kependudukan maupun pendidikan.

\section{Analisis Data}

\section{Analisis Gini Rasio}

Untuk mengetahui kemerataan distribusi pemilikan lahan dan pendapatan digunakan rumus gini rasio sebagai berikut:

$\mathrm{IG}=1-\sum_{1}^{n} f i\left(\mathrm{Y}_{\mathrm{i}}+\mathrm{Y}_{\mathrm{i}-1}\right)$

Keterangan:

IG = Indeks Gini

$\mathrm{Yi} \quad=$ proporsi jumlah rumah tangga petani kumulatif ke-i

$\mathrm{Y}_{\mathrm{i}-1} \quad=$ Yi sebelumnya

$\mathrm{Fi} \quad=$ frekuensi luas lahan/pendapatan yang dimiliki kumulatif ke-i

\section{Analisis Pendapatan Usahatani}

Pendapatan usahatani merupakan selisih antara penerimaan usahatani dengan pengeluaran usahatani (Soekartawi, 1995). Besarnya pendapatan usahatani sangat tergantung dengan besarnya penerimaan yang didapat. Penerimaan dihitung dengan rumus sebagai berikut:

$$
\mathrm{TR}=\mathrm{P} \times \mathrm{Q}
$$

\section{Keterangan:}

$$
\begin{array}{ll}
\mathrm{TR} & =\text { Penerimaan Usahatani }(\mathrm{Rp}) \\
\mathrm{P} & =\text { Harga gabah }(\mathrm{Rp} / \mathrm{Kg}) \\
\mathrm{Q} & =\text { Jumlah produksi gabah }(\mathrm{Kg})
\end{array}
$$

Pendapatan petani dari usahataninya dihitung dengan rumus sebagai berikut:

$$
\mathrm{Pd}=\mathrm{TR}-\mathrm{TC}
$$

Keterangan:

$\mathrm{Pd} \quad=$ Pendapatan Usahatani $(\mathrm{Rp})$

$\mathrm{TR} \quad=$ Penerimaan Usahatani $(\mathrm{Rp})$

Analisis Chi Square

$\mathrm{TC}=$ Pengeluaran Usahatani $(\mathrm{Rp})$

Hubungan antara luas pemilikan lahan pertanian dengan pendapatan usahatani digunakan analisis dengan menggunakan Tabel Kontingensi. Tabel Kontingensi merupakan 
tabel yang digunakan untuk mengukur hubungan (asosiasi) antara dua variabel kategori dimana tabel tersebut merangkum frekuensi bersama dari observasi pada setiap kategori variabel. Misalkan n sampel diklasifikasikan secara silang berdasarkan dua atribut dalam suatu tabel berukuran I x J, I merupakan kategori dari variabel X dan J merupakan kategori dari variabel Y. Sel pada tabel mewakili kemungkinan IJ muncul. Bentuk sederhana dari tabel kontongensi adalah tabel kontingesi $2 \times 2$.

Menurut Usman (2000) hipotesis yang diajukan adalah:

$\mathrm{H}_{0}$ : Tidak ada hubungan antara variabel 1 dan variabel 2 atau variabel 1 dan variabel 2 saling bebas (independen)

$\mathrm{H}_{1}$ : Ada hubungan antara variabel 1 dan variabel 2 atau variabel 1 dan variabel 2 saling berasosiasi

\section{Analisis Analytical Hierarchy Process (AHP)}

Kebijakan pertanahan terkait pemilikan lahan untuk menghindari ketimpangan yang terlampau besar dianalisis dengan AHP. Konsep dasar AHP adalah penggunaan matriks pairwise comparison (matriks perbandingan berpasangan) untuk menghasilkan bobot relatif antar kriteria maupun alternatif. Suatu kriteria akan dibandingkan dengan kriteria lainnya dalam hal seberapa penting terhadap pencapaian tujuan di atasnya (Saaty, 1986).

\section{Hasil dan Pembahasan}

\section{Distribusi Pemilikan Lahan}

Pemilikan dan penguasaan lahan yang belum tertib ialah mengenai pemilikan dan penguasaan dalam jumlah yang luas (Muharam 2015). Pemilikan lahan oleh petani yang berbeda-beda sangat mempengaruhi distribusi penguasaan lahan. Dapat dilihat dari hasil perhitungan distribusi pemilikan lahan di Desa Mulangsari yang menunjukkan nilai gini rasio 0,38 yang berarti bahwa terjadi ketimpangan pemilikan lahan yang tergolong dalam kriteria sedang. Hasil perhitungan distribusi pemilikan lahan di Desa Lemahduhur menunjukkan angka gini rasio 0,24, di mana hal ini menandakan bahwa tingkat ketimpangan pemilikan lahan di desa ini tergolong rendah.

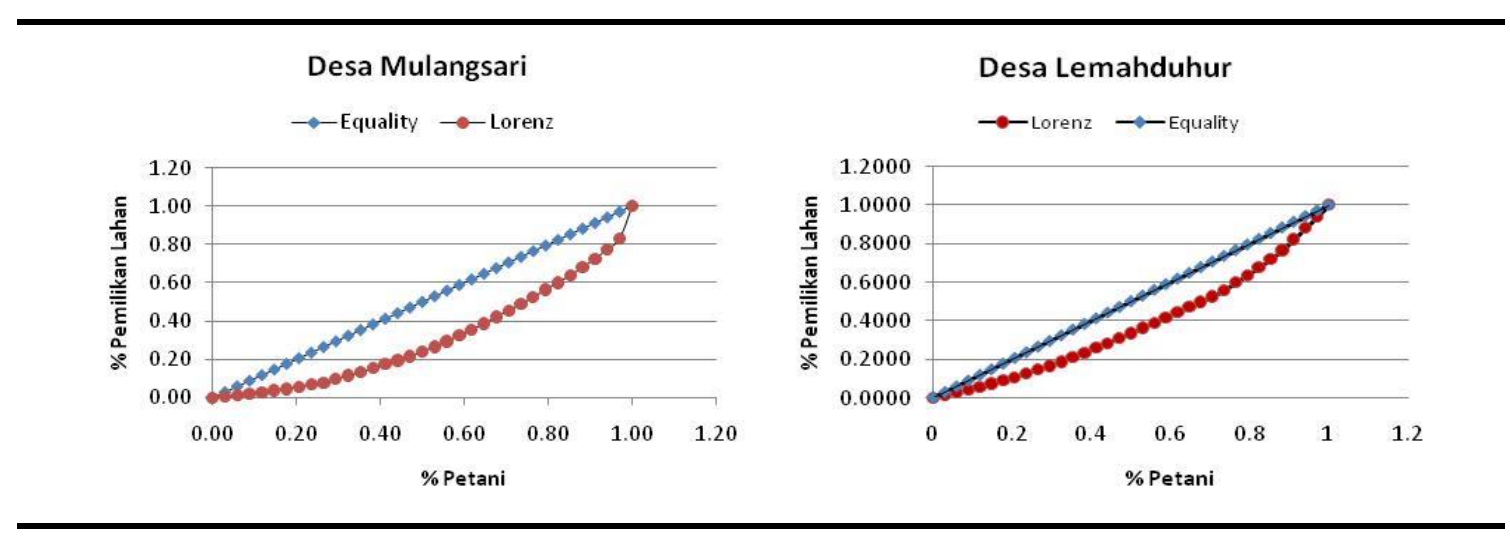

Gambar 1 Kurva Lorenz Pemilikan Lahan

\section{Pendapatan Usahatani}

Berdasarkan data perhitungan diketahui bahwa rata-rata pengeluaran usahatani padi di Desa Mulangsari adalah sebesar Rp5.762.723,00/ha dan di desa Lemahduhur sebesar Rp9.204.631,00/ha per musim tanam. Dari hasil penelitian juga diperoleh informasi bahwa jika petani memiliki lahan seluas satu hektar maka per musimnya dapat memperoleh 
penerimaan sebesar Rp14.050.798,00/ha/musim di Desa Mulangsari dan sebesar Rp25.889.411,00/ha/musim di Desa Lemahduhur. Penerimaan ini diperoleh dari hasil panen padi yang diproduksi oleh petani sebesar $\pm 4.015 \mathrm{~kg} / \mathrm{ha} /$ musim di Desa Mulangsari dan sebesar $\pm 5.628 \mathrm{~kg} / \mathrm{ha} /$ musim di Desa Lemahduhur. Dengan harga gabah basah, mengacu pada kebiasaan praktik jual beli gabah basah di kedua desa, sebesar Rp3.500,00/kg di Desa Mulangsari serta Rp4.600,00/kg di Desa Lemahduhur. Harga gabah basah di Desa Lemahduhur lebih mahal dikarenakan kualitas gabahnya yang lebih baik dibandingkan dengan gabah hasil panen para petani di Desa Mulangsari.

Dari penerimaan dan pengeluaran tersebut, dapat diketahui besaran pendapatan yang diperoleh oleh petani. Pendapatan usahatani petani responden di Desa Mulangsari adalah sebesar Rp8.621.276,00/ha/musim dan di Desa Lemahduhur sebesar Rp16.684.780,00/ha/musim. Jika pendapatan ini dikonversi ke tiap bulan, maka pendapatan yang diperoleh dari usahatani padi pada kisaran rata-rata Rp2.155.319,00/ha/bulan di Desa Mulangsari dan di Desa Lemahduhur sebesar Rp4.171.195,00/ha/bulan. Pendapatan inipun didapat hanya jika petani memiliki luas lahan sebesar 1 ha. Namun pada kenyataannya sebagian besar petani tidak memiliki lahan seluas 1 ha guna menopang kehidapan rumah tangganya. Pendapatan per bulan jika petani memiliki lahan seluas 1 ha menurut kriteria Badan Pusat Statistik (BPS 2016) ternyata belum mampu menopang kehidupan rumah tangga petani untuk hidup layak di Desa Mulangsari. Berdasarkan data BPS, bahwa ukuran Kebutuhan Hidup Layak (KHL) di Provinsi Jawa Barat adalah sebesar Rp946.689,00/jiwa/bulan. Sehingga jika rata-rata jumlah anggota keluarga petani responden di kedua desa adalah 3 orang, maka untuk hidup layak dibutuhkan biaya sebesar Rp2.840.067,00 per keluarga. Hal yang berbeda dialami oleh petani di Desa Lemahduhur karena pendapatan yang mereka peroleh jika memiliki 1 ha lahan dapat menopang kehidupan yang lebih dari layak untuk keluarganya.

Pendapatan per bulan petani dari hasil usahataninya berada di bawah angka biaya KHL dalam membiayai keluarganya. Hasil penelitian menunjukkan bahwa pendapatan petani per bulan dengan luas lahan yang dimiliki saat ini adalah rata-rata Rp742.464,00/bulan di Desa Mulangsari dan sebesar Rp2.149.286,00/bulan di Desa Lemahduhur. Dari hasil perhitungan, jika harga gabah berada di kisaran Rp3.500,00 maka luas lahan yang dibutuhkan 1 rumah tangga petani untuk memenuhi kebutuhan hidup layaknya adalah $12.186 \mathrm{~m}^{2}$ sedangkan jika harga gabah di kisaran $\mathrm{Rp} 4.600,00$ maka 1 rumah tangga petani memerlukan lahan seluas $7.944 \mathrm{~m}^{2}$ untuk bisa memenuhi kebutuhan hidup layak keluarganya.

Adanya ketimpangan distribusi pemilikan lahan memicu juga ketimpangan dalam distribusi pendapatan. Dari hasil perhitungan, didapatkan nilai Gini Rasio pendapatan sebesar 0,47 di Desa Mulangsari dan untuk Desa Lemahduhur nilai Gini Rasio pendapatannya sebesar 0,39. Pada kedua desa terjadi ketimpangan dalam distribusi pendapatan. Ketimpangan pendapatan di Desa Mulangsari termasuk dalam kategori tinggi sedangkan di Desa Lemahduhur termasuk dalam kategori sedang dan hampir masuk ke dalam kategori tinggi. Ketimpangan pendapatan di kedua desa lebih tinggi dibandingkan ketimpangan pemilikan lahan. Hal ini dapat terjadi dikarenakan selain pemilikan lahan, faktor lain seperti hasil produksi dan biaya produksi usahatani juga mempengaruhi besarnya pendapatan (Zikrina 2013). Dengan kata lain, semakin baik atau efisien petani dalam mengelola usahataninya, maka bisa memperoleh semakin tinggi hasil produksi sehingga pendapatan yang mereka terima juga akan meningkat (Ritonga 2012). 

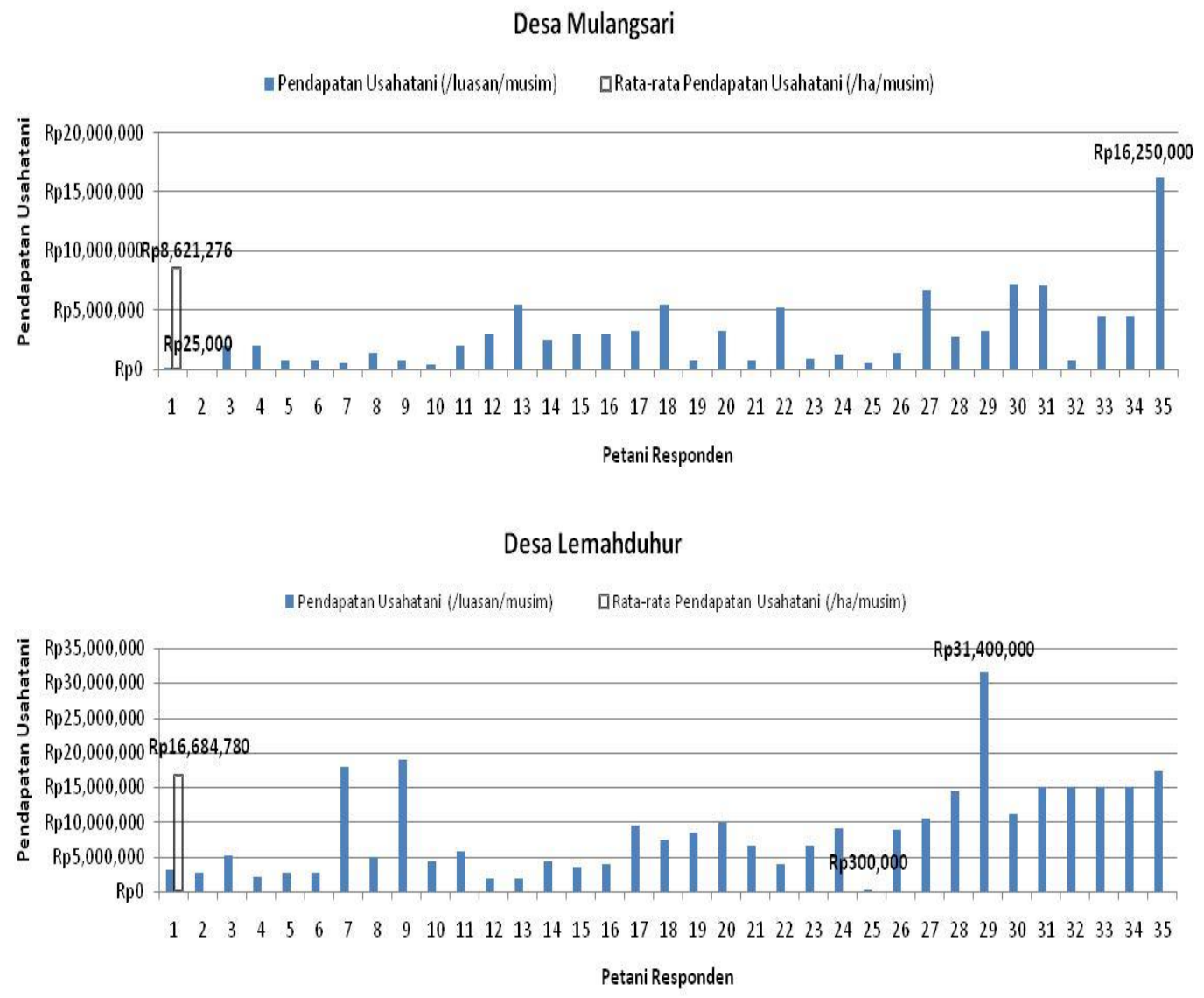

Gambar 2 Pendapatan Usahatani Petani Responden di Desa Mulangsari dan Desa Lemahduhur
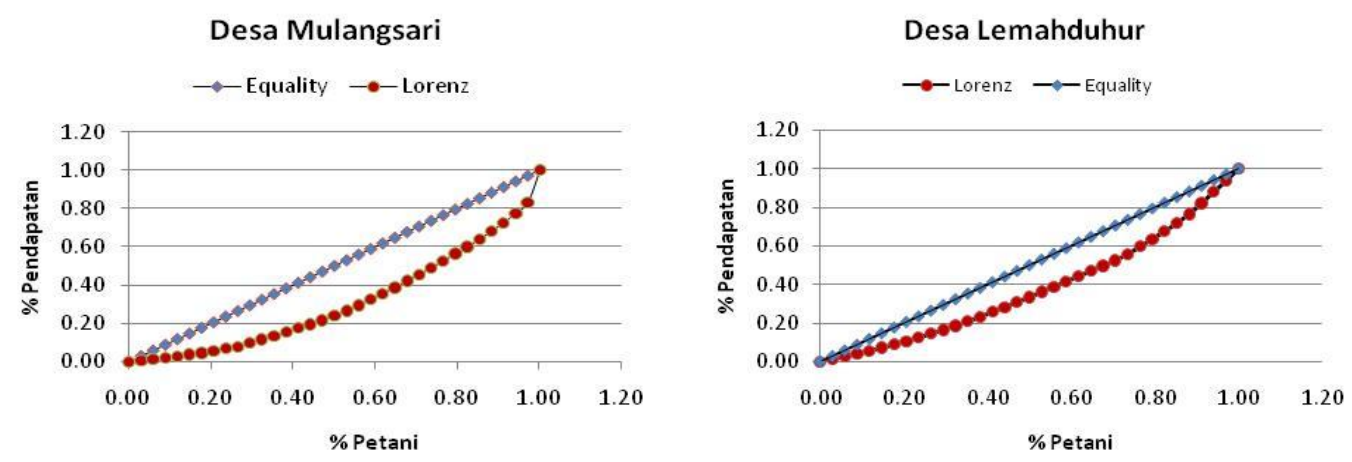

Gambar 3 Kurva Lorenz Pendapatan

Hubungan Struktur Pemilikan Lahan dan Pendapatan

Untuk mengetahui hubungan antara struktur pemilikan lahan pertanian dengan tingkat pendapatan petani digunakan analisis chi square dengan memakai tabel kontingensi. Hasil perhitungan dapat dilihat pada Tabel 2 dan Tabel 3. Dari hasil perhitungan analisis chi square untuk Desa Mulangsari didapat angka 0,17. Dengan 
membandingkan dengan nilai X2 tabel, maka nilai hasil perhitungan lebih kecil dari nilai X2 tabel. Kesimpulan yang bisa ditarik dari hasil perhitungan tersebut adalah menerima Ho yang berarti bahwa tidak ada hubungan antara luas lahan dengan pendapatan pada petani responden di Desa Mulangsari.

Tabel 2 Perhitungan Analisis Chi Square Petani Responden Desa Mulangsari

\begin{tabular}{crrr}
\hline \multirow{2}{*}{ Pendapatan } & \multicolumn{2}{c}{ Luas Lahan } & \multirow{2}{*}{ Total } \\
\cline { 2 - 3 } & $0-4999$ & $\geq 5000$ & \\
\hline <p 1 Juta & 10.63 & 1.37 & 12 \\
$>$ Rp 1 Juta & 20.37 & 2.63 & 23 \\
\hline Total & $\mathbf{3 1}$ & $\mathbf{4}$ & $\mathbf{3 5}$ \\
\hline
\end{tabular}

Sumber: Analisis Data Primer

Keterangan:

$\mathrm{X}^{2}=0,17$

Nilai X2 tabel dengan df 1 dan $p=0,001$ adalah 10,83 $>$ X2 hitung, terima Ho

Tabel 3 Perhitungan Analisis Chi Square Petani Responden Desa Lemahduhur

\begin{tabular}{crrl}
\hline \multirow{2}{*}{ Pendapatan } & \multicolumn{2}{c}{ Luas Lahan } & \multirow{2}{*}{ Total } \\
\cline { 2 - 3 } & $0-4999$ & $\geq 5000$ & 24 \\
< Rp 1 Juta & 17.14 & 6.86 & 24 \\
\hline Rp 1 Juta & 7.86 & 3.14 & 11 \\
\hline Total & 25 & 10 & 35 \\
\hline
\end{tabular}

Sumber: Analisis Data Primer

Keterangan:

$\mathrm{X} 2=22,31$

Nilai X2 tabel dengan df 1 dan $p=0,001$ adalah $10,83<X 2$ hitung, tolak Ho

Nilai hasil perhitungan analisis chi square di Desa Lemahduhur menunjukkan angka sebesar 22,31. Nilai tersebut lebih besar dibandingkan nilai X2 tabel, sehingga kesimpulan yang diambil dari hasil perhitungan adalah menolak Ho, yang berarti bahwa ada hubungan antara luas lahan dengan pendapatan petani responden di Desa Lemahduhur.

\section{Kebijakan Pertanahan}

Untuk mengetahui masukan dari pihak-pihak terkait terhadap kebijakan mengenai pemilikan lahan pertanian, digunakan analisis menggunakan Analytical Hierarchy Process (AHP). Penyusunan model hirarki pengambilan keputusan sebagaimana tersaji pada Gambar 10. Hasil perhitungan dengan metode AHP, dengan nilai Consistency Ratio 0,036 (lebih kecil dari 0,1 yang berarti konsistensi) didapatkan pilihan kebijakan seperti tersaji pada Tabel 15. Peringkat tiga teratas yaitu bahwa mayoritas responden pihak terkait kebijakan menghendaki adanya kebijakan di bidang pertanahan yang mengatur pemilikan lahan berdasarkan tingkat kehidupan layak. Kemudian juga diharapkan keberadaan aturan mengenai redistribusi tanah bagi lahan yang melebihi batas maksimal. 
H1 Fokus: Tujuan

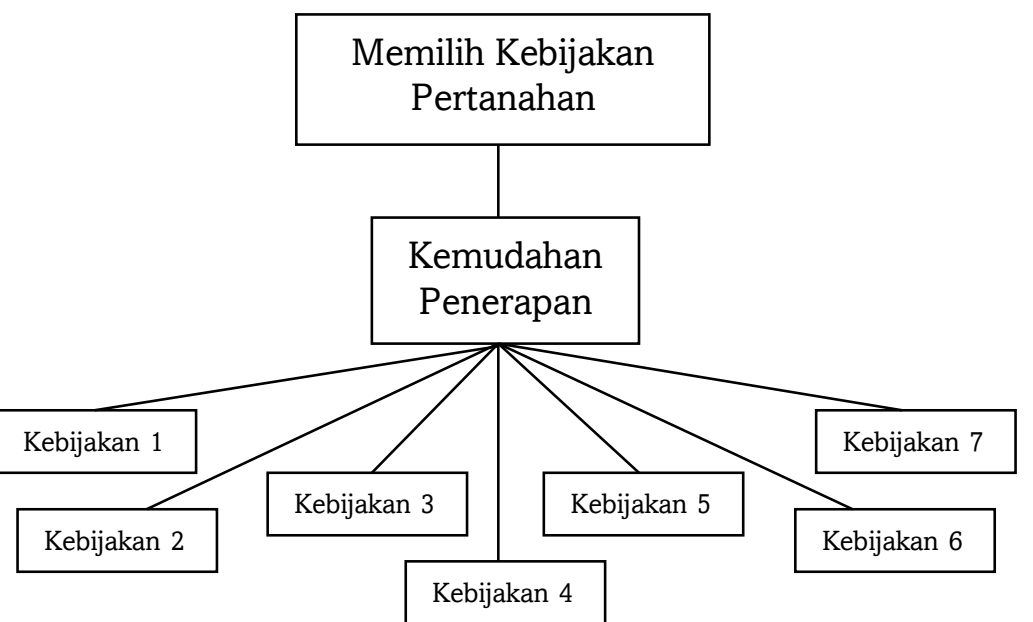

Gambar 4 Hirarki Memilih Kebijakan Pertanahan

Tabel 4 Hasil Akhir Perhitungan AHP Kebijakan Pertanahan terkait Pemilikan Lahan Pertanian

\begin{tabular}{|c|c|c|c|}
\hline No. & Kebijakan & Bobot $(\%)$ & Peringkat \\
\hline 1. & Pembatasan pemilikan melalui redistribusi & 29,1 & 2 \\
\hline 2. & $\begin{array}{l}\text { Pemilikan maksimal berdasarkan tingkat kepadatan penduduk } \\
\text { terbaru }\end{array}$ & 18,5 & 3 \\
\hline 3. & Pemilikan minimal berdasarkan tingkat hidup layak & 29,2 & 1 \\
\hline 4. & $\begin{array}{l}\text { Pemilikan bersama beberapa petani bagi tanah kelebihan } \\
\text { maksimal }\end{array}$ & 8,7 & 4 \\
\hline 5. & Pengenaan pajak progresif bagi tanah yang melebihi batas & 7,0 & 5 \\
\hline 6. & Penghentian bantuan subsidi bagi tanah yang melebihi batas & 4,8 & 6 \\
\hline 7. & $\begin{array}{l}\text { Tanah secara otomatis menjadi milik negara bagi yang } \\
\text { melebihi batas }\end{array}$ & 2,8 & 7 \\
\hline
\end{tabular}

Sumber: Analisis Data Primer

Dalam hal ini lahan kelebihan dari batas maksimal diatur oleh negara untuk diredistribusikan kepada para petani yang tidak memilik lahan ataupun yang memiliki lahan namun sempit (Baiduri 2014). Diharapkan juga terbitnya kebijakan yang mengatur pembatasan pemilikan lahan pertanian berdasarkan tingkat kepadatan penduduk terbaru. Kebijakan ini dimaksudkan untuk memperbarui aturan yang sebelumnya telah ada di mana kriteria kepadatan penduduk dalam aturan yang lama dianggap sudah tidak relevan dengan keadaan masa sekarang. Kepastian kepemilikan lahandiyakini penting untuk investasi pertanian (Nguyen 2012). Kebijakan pertanahan yang diperbarui adalah hal penting untuk mengatasi hambatan dalam penegakan hak atas tanah petani dalam konteks produksi pertanian secara kecil (Zhao 2012).

\section{KESIMPULAN}

Nilai koefisien gini dari hasil perhitungan menunjukkan sebesar 0.38 di Desa Mulangsari yang masuk kategori sedang, sedangkan ketimpangan pemilikan lahan di Desa Lemahduhur masuk kategori rendah dengan nilai koefisien gini sebesar 0.24. Sehingga dapat dikatakan struktur pemilikan tanah pertanian di kedua lokasi penelitian mengalami ketimpangan rendah mendekati sedang. Ketimpangan pendapatan petani di Desa Mulangsari tergolong tinggi, dengan nila koefisien gini sebesar 0.47. Ketimpangan 
pendapatan di Desa Lemahduhur masuk dalam kategori sedang, dengan nilai koefisien gini 0.39. Hasil analisis chi square menunjukkan tidak ada hubungan antara luas lahan dengan pendapatan di Desa Mulangsari sebaliknya di Desa Lemahduhur, terdapat hubungan antara luas lahan dengan pendapatan. Kebijakan pembatasan pemilikan lahan berdasarkan tingkat kehidupan layak dapat dijadikan alternatif pertama. Selanjutnya adalah kebijakan redistribusi lahan bagi lahan-lahan yang melebihi batasan maksimal bisa diterapkan untuk melengkapi kebijakan pertama. Alternatif ketiga adalah kebijakan mengenai pengaturan pembatasan kepemilikan berdasarkan tingkat kepadatan penduduk yang terbaru. Dari kesimpulan tersebut maka upaya-upaya yang dapat dilakukan agar distribusi pemilikan lahan dan pendapatan tidak timpang adalah dengan meningkatkan akses lahan untuk petani dan mencegah terjadinya konversi lahan. Mengingat pendapatan petani yang diterima relatif kecil, maka dianjurkan kepada petani untuk menerapkan intensifikasi pada usahataninya. Sehingga dengan luas lahan yang tetap, dapat meningkatkan hasil produksinya yang berdampak meningkatkan pendapatannya. Upaya meningkatkan pendapatan petani juga dapat dilakukan dengan menciptakan peluang usaha baru di perdesaan agar petani dapat memperoleh tambahan pendapatan dari usaha lain di luar usahatani.

\section{DAFTAR PUSTAKA}

Asryad, Sitanala dan Ernan Rustiadi. 2008. Penyelamatan Tanah, Air, dan Lingkungan. Jakarta (ID): Crestpent Press dan Yayasan Obor Indonesia.

[Bappenas] Badan Perencanaan Pembangunan Nasional. 2015. Rencana Pembangunan Jangka Menengah Nasional 2015-2019. Jakarta (ID): Bappenas.

[BPS] Badan Pusat Statistik. 2013. Sensus Pertanian 2013. Jakarta (ID): BPS.

[BPS] Badan Pusat Statistik. 2016. Tabel Dinamis Kehidupan Hidup Layak. [Internet]. [diunduh 10 April 2017]. Tersedia pada: http// www.bps.go.id/ linkTable Dinamis/view/id/1212

Baiduri, Intan. 2014. Upaya Penegakan Hukum Kepemilikan Tanah Pertanian Kering yang Melampaui Batas Maksimum di Daerah Sangat Padat Penduduk berdasarkan UU Nomor 56 Prp Tahun 1960 tentang Penetapan Luas Tanah Pertanian. Jurnal Beraja Inti. 3(9):1-15.

Muharam, Noviasih. 2015. Analisis Penerapan Batas Maksimum Kepemilikan Tanah terhadap Luas Tanah Pertanian (Studi Kasus Pada Kantor Pertanahan Lampung Selatan). Keadilan Progresif. 6(1):76-86.

Nguyen, H.L. 2012. Agriculture Land Tenure Security Under Vietnamese Law. Land Tenure Journal. 2:67-93.

Pemerintah Republik Indonesia. 1960. Undang-Undang Republik Indonesia Nomor 56 Prp Tahun 1960 tentang Penetapan Luas Tanah Pertanian. Jakarta (ID): Sekretariat Negara.

Ritonga, Ajuan. 2012. Analisis Pengelolaan Usaha Padi Sawah berdasarkan Kepemilikan Lahan. Journal on Social Economics of Agriculture and Agribusiness. 1(1):1-12.

Saaty, Thomas L. Decision Making for Leaders The Analytical Hierarchy Process for Decisions. Pitsburgh: RWS Publ.

Singarimbun, Masri dan Effendi Sofian. 1995. Metode Penelitian Survei. Jakarta (ID): PT. Pustaka LP3ES.

Soekartawi. 1995. Analisis Usahatani. Jakarta(ID): UI Press.

Usman,H dan R. Purnomo Setiady Akbar. 2000. Pengantar Statistika. Jakarta (ID): Bumi Aksara.

Zhao, Yongjun. 2012. Rethinking China's Land Tenure Reform: The Emergence of Farmers' Land Shareholding Cooperatives. Land Tenure Journal. 2:95-117.

Zikrina. 2013. Faktor-faktor yang Mempengaruhi Pendapatan Petani Padi Organik di Kabupaten Serdang Bedagai (Studi Kasus: Desa Lubuk Bayas, Kecamatan Perbaungan). Journal on Social Economics of Agriculture and Agribusiness. 2(1):1-15. 